\title{
GATOR Complex Protein NPRL2
}

National Cancer Institute

\section{Source}

National Cancer Institute. GATOR Complex Protein NPRL2. NCI Thesaurus. Code C63531.

GAT OR complex protein NPRL2 (380 aa, $44 \mathrm{kDa}$ ) is encoded by the human NPRL2 gene. This protein plays a role in the regulation of signaling. 